\title{
THERMAL STABILITY AND GASEOUS EXHAUST PRODUCTS OF BOVINE LEATHER FOR FIREFIGHTER BOOTS
}

\author{
Sandra Flinčec Grgac ${ }^{1}$, Franka Žuvela Bošnjak ${ }^{1}$, Boris Valečić ${ }^{1}$, Jadranka Akalović ${ }^{1}$ \\ ${ }^{1}$ Sveučilište u Zagrebu Tekstilno-tehnološki fakultet, Prilaz baruna Filipovića 28a, 10000 Zagreb, \\ Hrvatska \\ Viner d.o.o., Rusanova 1, 33000 Virovitica, Hrvatska
}

E-mail: sflincec@ttf.hr, franka.zuvela.bosnjak@ttf.hr, bvalecic@gmail.com

\begin{abstract}
Original Scientific Paper
Abstract

UDK: [685.345:675.031.1]:665.7.035.5

This paper aims to investigate fire resistance properties of two samples of fireproof bovine leather; both with smooth and perforated brushed surfaces. Apart from flammability and flame spreading, an important property is heat resistance and the development of gaseous products that occur during heat degradation. For the purpose of characterizing those properties, cowhide leather samples were exposed to thermogravimetric analysis (TGA) of monitoring gaseous degradation products (TG-IR) during decomposition. Considering the results of fire resistance, it can be concluded that tested samples of smooth bovine leather show satisfactory stability to the influence of flame and heat, while perforated brushed fireproof leather with artificial surface was partially pouched and gathered in the area of direct contact with flame. Both samples show similar behavior during TGA, but differences have been observed in the analysis of gaseous degradation products.
\end{abstract}

Keywords

bovine leather, fire extinguisher, TG-IR analysis, fire resistance

\section{INTRODUCTION}

Firefighter profession is one of highly hazardous professions, so firefighting equipment plays an important role in personal protection of firefighters. Boots as a part of the equipment are extremely important for protecting feet from high temperatures, dangerous liquids (chemicals), along with mechanical and electrical activity.

There are several types of firefighter footwear for different purposes due to different types of work that firefighters perform. Firefighter footwear designed for safe protection from hazards during firefighting is resistant to heat and mechanical damage. At the same time, this footwear has good anti-static and excellent insulating properties at high and low temperatures [1]. The fiber structure of leather tissue made of collagen fibers gives leather certain mechanical properties that depend on the type and quality of raw leather, as well as on technological processing operations. Bovine leather generally has solid and tight collagen tissue, especially in bend parts, which allows the production of leather with high resistance to mechanical stress [2].

Bend leather is most commonly used in the production of shoe parts exposed to greatest mechanical and thermal influences. It consists of densely and evenly intertwined leather tissue of even thickness, which provides good mechanical properties. A greater number of vertical fibers give firmer and thicker leather tissue. Bend leather is firmest and densest, providing good mechanical and thermal properties [3].

Firefighter boots are usually made of bovine box leather. Box leather tanned with chrome or vegetable tanning agents is used for upper parts of footwear and for other leather garments. They are mainly produced with a smooth, natural face or cracked and embossed face.

The main characteristics of box leather are: fullness, plucking, softness, good strength, elasticity and dense leather tissue. These properties are linked to the fibrous structure of leather tissue which is formed of collagen fibers, depending on the type and quality of raw leather and performed technological processing operations [2]. Monitoring of thermal decomposition of leather has so far been used to identify historical and cultural objects made of leather, defining differences between natural and artificial leather, restoration of historical objects and for the purpose of assessing different impacts on the application and the environment [4].

Firefighter footwear is classified and tested according to HRN EN ISO 15090: 2012.

SPECIAL FIGHTER CE 0197 EN 15090:2012 HI3 CI SRC - Type F2A

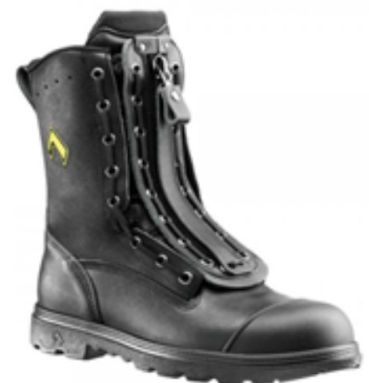

Figure 1. Firefighter boot, Special Fighter

The upper side is made of first-class bovine leather of thickness up to $3 \mathrm{~mm}$, with very firm and stable structure, excellent ventilation and homogeneous and 
resilient leather surface which does not contain harmful substances.

The percentage of leather in these firefighter boots is $70 \%$. Only top quality leather is used since it has to be airy, hydrophobic, free of harmful substances (PCP1 and Chrome VI etc.), with the addition of pigments that reflect the sunlight. The GBR-TEX $®$ Cambrelle ${ }^{\circledR}$ material is used for footwear lining. It is a translucent and watertight four-layer laminate with a PTFE2 membrane which endures temperatures up to $260{ }^{\circ} \mathrm{C}$ [5]. It was tested on 500,000 "rubbing" fabrics, which is twice the standard. The boot with this lining provides multiple types of protection and maintains favorable microclimatic conditions. The boot has a rubber outsole, a "self-cleaning" V-profile that provides better foothold and pulling power on uneven grounds. Such outsoles have a relatively small weight and leave no traces. They are resistant to oil and fuel. The outsole is fitted with a metal footstool for protection against sharp objects. The MLS system evenly distributes the weight of the body to the outsole, relieves spinal load, absorbs and distributes energy during motion, isolates the upper part from heat and cold and permanently connects the upper leather part, insole and outsole.

On the front side of the upper part of the boot, a TPU cap is also built in along with steel. Cap serves as protection against abrasion and various external influences such as oil and fuel, thus prolonging the lifetime of the boot [5].

According to the HRN EN ISO 15090: 2012, firefighter footwear is tested against the influence of temperature according to the following parameters:

1. Contact with hot surface: sand temperature of $250^{\circ} \mathrm{C}$, duration time of 40 minutes. After the test, the material should not be visibly damaged and the degree of insulation must be satisfying.

2. Radiation: the entire boot is exposed to heat of $2 \mathrm{~W}$ / cm. (approximately $300^{\circ} \mathrm{C}$ ), duration time of 3 minutes. The material should not be visibly damaged.

3. Flame directed to the upper side of the boot: All upper materials were tested against open flame for 15 seconds. After flame retardation, the materials should not burn for longer than 2 seconds and should not radiate the stored heat for longer than 5 seconds [6].

PCP - pentachlorophenol, used to prevent fungal growth in the leather industry

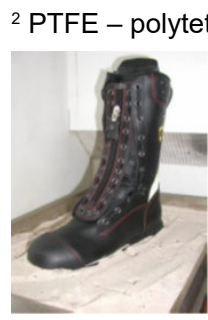

a

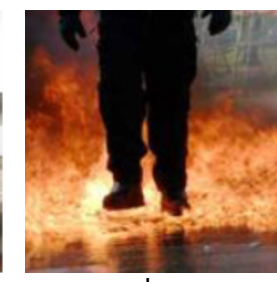

b

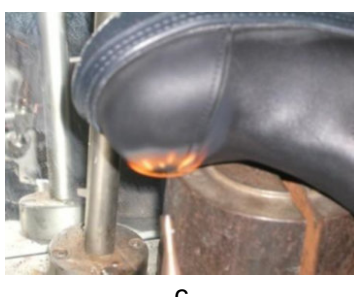

Figure 2. Testing of boot according to HRN EN ISO 15090: 2012 a) outsole with hot surface, b) radiation and c) flame directed to the upper side of boot
Table 1. Classification of firefighter footwear according to HRN EN ISO 15090: 2012

\begin{tabular}{|c|l|}
\hline Code 1 & $\begin{array}{l}\text { Footwear made of leather or other materials, with the } \\
\text { exception of full rubber or footwear made of polymers }\end{array}$ \\
\hline Code 2 & $\begin{array}{l}\text { Footwear made of full rubber or footwear made entirely } \\
\text { of polymers }\end{array}$ \\
\hline
\end{tabular}

Table 2. Types of firefighter footwear according to HRN EN ISO 15090:2012

\begin{tabular}{|c|l|}
\hline Type 1 & $\begin{array}{l}\text { Suitable for general technical assistance (e.g. TIP 1, HI1) } \\
\text { and for outdoor firefighting exclusively (e.g. Type 1 HI2, } \\
\text { Type 1 HI3) }\end{array}$ \\
\hline Type 2 & $\begin{array}{l}\text { Heavy, modeled for basic protection, suitable for } \\
\text { intervention indoors and other fires of all kinds; Standard } \\
\text { firefighter boots (e.g. Type } 2 \mathrm{HI} 2, \text { Type } 2 \mathrm{HI} 3)\end{array}$ \\
\hline Type 3 & $\begin{array}{l}\text { Special protection, suitable for use at special risks such as } \\
\text { hazardous materials intervention; also suitable for all } \\
\text { kinds of firefighting (e.g. Type } 3 \text { HI2, Type } 3 \mathrm{HI} 3)\end{array}$ \\
\hline The meaning of symbol abbreviation \\
\hline HI1 & $\begin{array}{l}\text { Heat insulation effect level at the outsole area at } 150{ }^{\circ} \mathrm{C} / \\
30 \text { min. }\end{array}$ \\
\hline HI3 & $\begin{array}{l}\text { Heat insulation effect level at the outsole area at } 250{ }^{\circ} \mathrm{C} / \\
40 \text { min. }\end{array}$ \\
\hline
\end{tabular}

The International Standard HRN EN ISO 20345: 2012 sets the basic and additional requirements for safety footwear. This includes mechanical and thermal risk, slip resistance and ergonomic behavior. The classification system used to determine the protection offered by footwear is shown in table 3 [7].

Table 3. Classification system for determination of protection

\begin{tabular}{|c|l|}
\hline $\begin{array}{c}\text { Oznaka } \\
\text { klasifikacije }\end{array}$ & \multicolumn{1}{|c|}{ Opis klasifikacije } \\
\hline SB & $\begin{array}{l}\text { A safety cap that protects toes from injury caused by } \\
\text { falling objects. The protection level is 200 J. } \\
\text { Prevention of injury caused by pressure on the toes } \\
\text { pressed against a heavy object. The level of this } \\
\text { protection is 15 kN. }\end{array}$ \\
\hline SBP & As SB standard + resistance to penetration. \\
\hline S1 & $\begin{array}{l}\text { As SB standard + closed heel and anti-static } \\
\text { properties, resistance to the absorption of fuel, oil } \\
\text { and energy of that part. }\end{array}$ \\
\hline S1P & As S1 standard + resistance to penetration. \\
\hline S2 & $\begin{array}{l}\text { As S1 standard + resistance to penetration and } \\
\text { water absorption. }\end{array}$ \\
\hline S3 & $\begin{array}{l}\text { As S4 standard + ribbed outsole and penetration } \\
\text { resistance }\end{array}$ \\
\hline S4 & $\begin{array}{l}\text { Toe cap, offering 200J protection. All rubber } \\
\text { footwear or footwear made of polymers with anti- } \\
\text { static properties. Resistance to heating oil, energy } \\
\text { absorption on the heel and closed heel. }\end{array}$ \\
\hline S5 & $\begin{array}{l}\text { As S4 standard + ribbed outsole and penetration } \\
\text { resistance. }\end{array}$ \\
\hline HI & Heat insulation \\
\hline Cl & Cold Insulation \\
\hline WRU & Water-repellent upper part \\
\hline WR & Impermeable \\
\hline HRO & Electrically insulated footwear \\
\hline Anti-slip outsole \\
\hline Resistance to heat contact \\
\hline Protection of metatarsal bone \\
\hline Protection of ankle \\
\hline Outsole resistance to fuels \\
\hline SO
\end{tabular}

\section{EXPERIMNTAL}

\subsection{Description of samples}

Two samples of bovine leather were exposed to heat stability testing and fire resistance testing. Fireproof bovine box leather (VK1), 2.3-2.5 mm thick, is used to produce upper parts of firefighter boots. Perforated brushed bovine leather (VK2) with artificial face is most commonly used for collar of firefighter boots. Both samples are black. 


\subsection{Procedure of Heat Stability Test}

Thermogravimetric analysis (TGA) of leather samples was performed using a PerkinElmer analyzer controlled by a PC system in atmosphere with a synthetic air flow ( $30 \%$ oxygen, flow rate $60 \mathrm{ml} / \mathrm{min}$ ). Thermogravimetric (TG) of samples was obtained at temperature range of $50^{\circ} \mathrm{C}$ to $850^{\circ} \mathrm{C}$, at a heating rate of $30^{\circ} \mathrm{C} / \mathrm{min}$. Before thermal analysis, leather samples were cut into pieces of average weight of $1 \mathrm{mg}$. The analyzed samples weighed approximately $6 \mathrm{mg}$. Samples were also studied by combined thermogravimetric analysis with monitoring of gaseous products of degradation by infrared spectrometer (TG-IR technique) in order to gain insight into the composition of gaseous degradation products. Thermal station for gas analysis (EGA) equipped with a detector was used for TG-IR analysis. The transmission line, high-temperature transfer station and TG interface were maintained at $280{ }^{\circ} \mathrm{C}$ during measurement to prevent gas condensation. The peristaltic pump transferred the generated gases at a flow rate of $60 \mathrm{ml} / \mathrm{min}$.

\subsection{Proceeding for testing of fire resistance properties}

The test was conducted according to HRN EN ISO 15025:2016 i HRN EN ISO 15090:2012, t, 7.3. [8, 9]. The samples were subjected to standard atmosphere, temperature of $23^{\circ} \mathrm{C}\left( \pm 2^{\circ} \mathrm{C}\right)$ and relative humidity of $50 \%( \pm 5 \%)$ before testing.

\section{RESULTS AND DISCUSION}

The results of thermal stability testing and gas products during thermal decomposition are shown in figures 3,4 , 5 and 6.

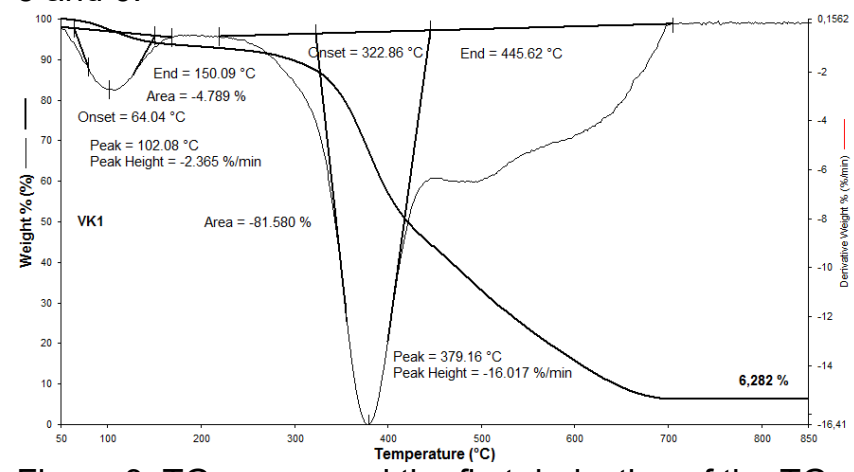

Figure 3: TG curves and the first derivation of the TG curve (dTG) of bovine leather sample for the production of firefighter boots (VK1)

From the obtained thermogravimetric curves (TG) and their first derivations (DTG), it is clear that the degradation of samples VK1 and VK2 (figure 3 and figure 5) takes place in two degradation stages. The first stages of dynamic degradation were registered at temperature of $102.08{ }^{\circ} \mathrm{C}$ at VK1 and $92.78^{\circ} \mathrm{C}$ at VK2, in which the unbound and crystal-bound water was released. This can be observed in figure $4 \mathrm{~b}$ and figure $6 \mathrm{~b}$ from values of detected gaseous water products and $\mathrm{H}_{2}$. Mass loss of $16.017 \%$ per minute was registered in the second stage of dynamic degradation of VK1 at $379.16{ }^{\circ} \mathrm{C}$ (figure 3 ), whereas the loss of mass was $16.148 \%$ per minute at $367.65{ }^{\circ} \mathrm{C}$ for the VK2 sample (figure 5). This degradation dynamics in both samples indicates a decomposition of the leather tissue structure caused by drying and melting of the crystalline collagen structure with the emergence of the following gaseous products (figures $4 \mathrm{c}$ and d, figures 6 c and d): crystal bound water at value of $3500-4000$ $\mathrm{cm}^{-1}, \mathrm{CO}_{2}$ confirms the peak between $2402-2240 \mathrm{~cm}^{-1}$ and $736-605 \mathrm{~cm}^{-1}$ wave numbers, which can occur during degradation of leather tissue by direct decarboxylation $-\mathrm{COOH}$ and by condensation reactions which include peptide -CO- groups. This can also occur due to internal oxidation of other organic groups in leather tissue. $\mathrm{CO}$ was in the $2240-2060 \mathrm{~cm}^{-1}$ range, $\mathrm{NH}_{3}$ was identified in both samples (VK1 and VK2) where narrow peaks were observed in the wave domain of 1200 up to $750 \mathrm{~cm}^{-1}$ with characteristic ribbons at $964,930 \mathrm{~cm}^{-1}$.

$\mathrm{CH}_{4}$ and $\mathrm{C}_{2} \mathrm{H}_{6}$ gaseous degradation products are visible in the range of 2800 to $3000 \mathrm{~cm}^{-1}$ in the VK2 sample (figure $6 \mathrm{~d}$ ). Products of HNCO at wave number 2080 $\mathrm{cm}^{-1}$ were recorded in the same sample, as a result of the disintegration of the collagen. The aldehyde $\mathrm{C}=\mathrm{O}$ gas product was recorded at wave number $1710 \mathrm{~cm}^{-1}$ $[4,10]$.

Due to the emergence of a larger quantity of different gaseous products during thermal decomposition, the VK2 sample indicates possible adverse impacts on health and the environment.
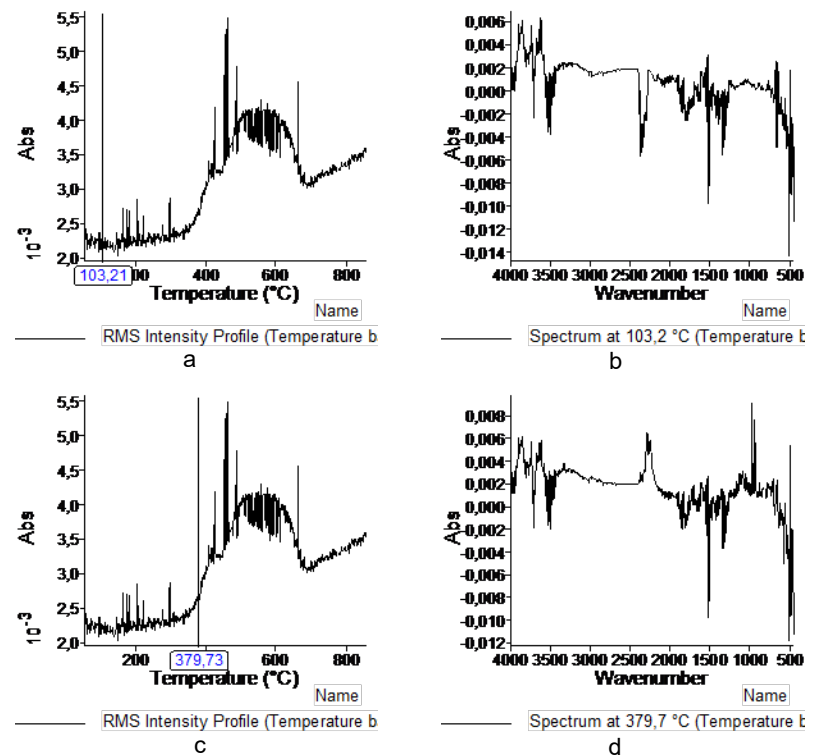

Figure 4: TG-IR analysis of bovine leather VK1 sample: a) the absorption spectrum of higher concentration of gases, b) gases measured on IR at temperature 103,2 ${ }^{\circ} \mathrm{C}, \mathrm{c}$ ) another absorption spectrum, d) gases measured at IR at temperature $379,73^{\circ} \mathrm{C}$

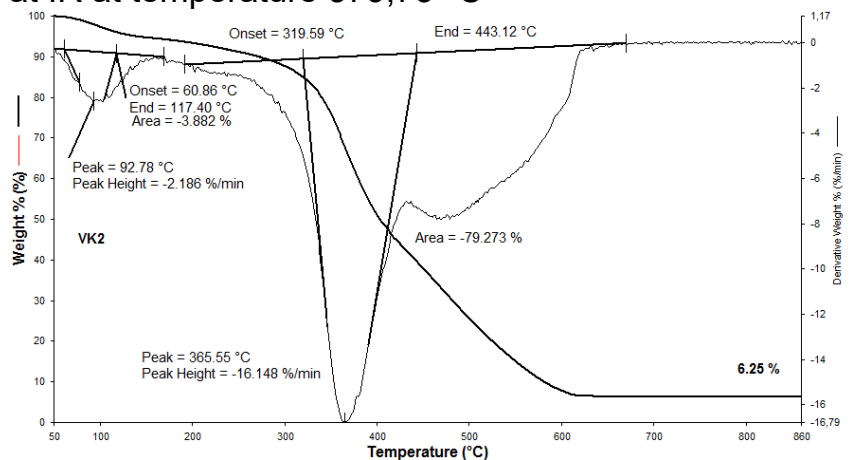

Figure 5: TG curves and the first derivation of the TG 
curve (dTG) for the sample of perforated bovine leather with artificial face, used in the production of firefighter boot (VK2)
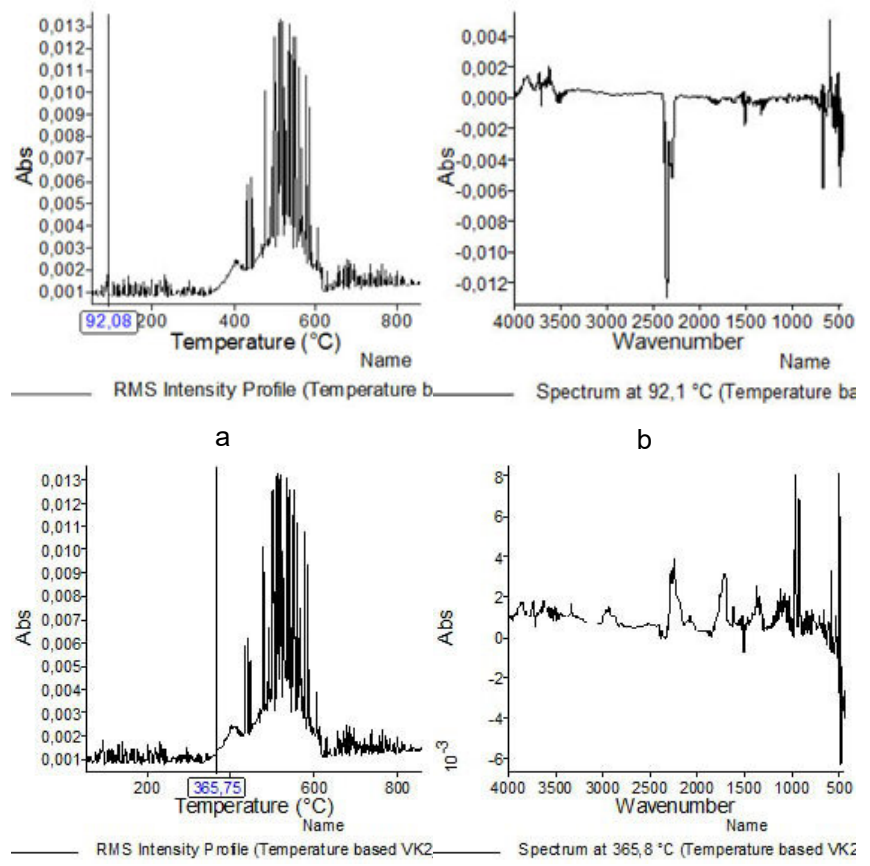

Figure 6: TG-IR analysis of bovine leather VK2 sample: a) the absorption spectrum of higher concentration of gases, b) gases measured on IR at temperature 92,21 ${ }^{\circ} \mathrm{C}, \mathrm{c}$ ) another absorption spectrum, d) gases measured on IR at temperature $365,75^{\circ} \mathrm{C}$

\subsection{Results of fire resistance testing}

After the flames were extinguished, neither of the samples continued to burn. Fireproof leather box VK1 was not damaged and proved to be an adequate material for the upper part of firefighter boots. VK2 sample of perforated bovine leather with artificial face was partially carbonized and shrank in the center (figure 7), where it was leaning against the flames. Due to the above mentioned damages and deformation, the VK2 sample is an inadequate material for the production of parts for firefighter boots.

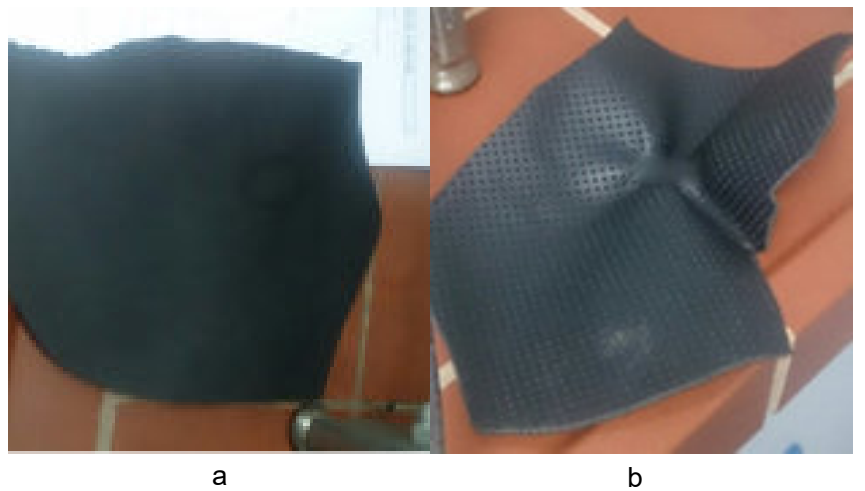

Figure 7: Samples after conducted fire resistance test: a) VK1, b) VK2

\section{CONCLUSION}

Thermogravimetric analysis of bovine leather samples indicates their approximately equal thermal stability. A more detailed analysis of thermogravimetric curves clearly shows that the VK1 sample has higher thermal stability, since the final residue is formed at $700{ }^{\circ} \mathrm{C}$,

while the residue in the VK2 sample is formed at temperature of $600{ }^{\circ} \mathrm{C}$. Gaseous degradation products clearly indicate the presence of different gases. In the sample of perforated bovine leather, the appearance of a gaseous isocyanate is evident, which may indicate the application of polyurethane face finish of perforated bovine leather VK2. Both samples produce gaseous $\mathrm{NH}_{3}$ during heat degradation which is toxic and corrosive, but the analyses of the recorded gaseous spectra in the entire range of thermal decomposition show that $\mathrm{NH}_{3}$ has not been detected above temperatures of $500{ }^{\circ} \mathrm{C}$. A higher number of potentially harmful gases was observed in the VK2 sample and can be associated with the type and structure of the finish on leather face. Sample VK1 shows greater stability to open flame and releases less gaseous products during heat degradation and is therefore much more favorable for the production of firefighter boots.

Further research will attempt to study the impact of different more environmentally-friendly resources which can reduce the flammability of bovine leather with the aim of minimizing gaseous products that are harmful to the environment.

\section{ACKNOWLEDGEMENTS}

The work was funded by means of support for the research TP8/17, Functionalization and Characterization of Textile Materials to Obtain Protective Properties, Principal Sandra Flinčec Grgac, $\mathrm{PhD}$.

The paper was published at the $7^{\text {th }}$ International Scientific and Professional Conference on Occupational Safety and Health in Zadar, Croatia.

\section{LITERATURE}

[1] Park, $H$. et al: Effect of firefighters personal protective equipment on gait, Applied Ergonomics, Vol. 48 (2015), pp. 42-48, ISSN 0003-6870

[2] Grgurić, H.i sur.: Tehnologija kože i krzna, Zajednica kem., kožarskih, obućarskih, gum. i rud. organizacija, Zagreb, (1985)

[3] Radanović, Z.: Poznavanje kožarskih materijala i njihovo ispitivanje, Zagreb, (1989)

[4] Marcillaa, A. et al: Study of the influence of $\mathrm{NaOH}$ treatment on the pyrolysis of different leather tanned using thermogravimetric analysis and Py/GC-MS system, Journal of Analytical and Applied Pyrolysis, Vol. 92 (2011), pp. 194-201, ISSN: 0165-2370

[5] http://hzzzsr.hr/wp_content/uploads/2016/11/Osobna_zastit na_o prema_za_zastitu_nogu_i_stopala.pdf, accessed on 20 January, 2019

[6] www.financ-fire.com/Norme.pdf, accessed on 20 January, 2019

[7] www.financ-fire.com/Proizvodnja.pdf, accessed on 20 January, 2019

[8] HRN EN ISO 15025:2016. Zaštitna odjeća - Zaštita od plamena - Metoda ispitivanja ograničenog širenje plamena

[9] HRN EN ISO 15090:2012, t,7.3 - Obuća za vatrogasce Ispitivanje otpornosti na gorenje

[10] Bańón, E. et al: Kinetic model of the thermal pyrolysis of chrome tanned leather treated with $\mathrm{NaOH}$ under different conditions using thermogravimetric analysis, Waste Management, Vol. 48 (2016), pp. 285-299, ISSN: 0956053X 